\title{
EXERGAMES E DIDATTICA DELLE ATTIVITÀ MOTORIE E SPORTIVE
}

\author{
Di Tore A. ${ }^{1}$, Raiola G. ${ }^{1}$
}

\begin{abstract}
The term "exergames" refers to a category of video games in which the interaction is not based only on hand-eye coordination, but on the whole body, through the use of non-standard controllers, like Nintendo Wiimote or Balance Board and Microsoft Kinect sensor. The exergames were immediately hailed as a welcome development, for the contribution they offer as a weapon against a sedentary lifestyle and the level of user involvement, which adds to the traditional value of video games the attractiveness of natural interfaces. The current trend is to consider how the exergames present many potential advantages in the context of physical education and wellness promotion of. However, the current generation of exergames is not designed specifically to support teaching of motor activities or rehabilitation. There are no products that can count on the basis of a robust theoretical framework and that are oriented to the acquisition of specific motor skills, for use in physical education teaching and rehabilitation.

Knowledge of basic mechanisms of motor control and of dynamics connected to motor skills learning may be the theoretical support to the design and development of exergames.
\end{abstract}

Keywords: physical education, sport, Kinect, Balance Board, Wiimote

| ${ }^{1}$ University of Salerno, Italy 


\begin{abstract}
Con "exergames" ci si riferisce ad una categoria di videogiochi in cui l'interazione non è basata sulla solo sulla coordinazione occhio-mano, ma sull'intero corpo, grazie all'utilizzo di controller non standard, come il WiiMote o la Balance Board di Nintendo e il sensore Microsoft Kinect. Gli exergames sono stati salutati da subito come una novità positiva, per il contributo che offrono come arma contro uno stile di vita sedentario e per il livello di coinvolgimento dell'utente, che unisce al tradizionale valore aggiunto dei videogames l'attrattiva delle interfacce naturali. La tendenza attuale è di considerare come gli exergames presentino numerosi vantaggi potenziali in ambito motorio e di promozione del benessere. Tuttavia, l'attuale generazione di exergames non è progettata specificamente per essere di supporto alla didattica delle attività motorie o alla riabilitazione. Non sono diffusi prodotti che possano contare sulla base di un robusto framework teorico e che siano orientati alla acquisizione di specifiche motor skills, da utilizzare nell'ambito della didattica delle scienze motorie e della riabilitazione.

La conoscenza dei meccanismi fondamentali del controllo motorio e delle dinamiche legate all'apprendimento delle abilità motorie può costituire il supporto teorico al design e allo sviluppo di exergames.
\end{abstract}

\title{
Introduzione
}

Il termine "exergame" viene utilizzato per definire il connubio della dimensione videoludica con l'esercizio fisico. In particolare, con exergame ci si riferisce ad una categoria di videogiochi in cui l'interazione non è basata sulla solo sulla coordinazione occhio-mano, ma sull'intero corpo. L'interazione basata sull'intero corpo è resa possibile da una serie di controller non standard, come, ad esempio, il WiiMote e la Balance Board di Nintendo, collegati alla console Wii, e il sensore Microsoft Kinect, diffuso come accessorio della console Xbox.

Gli exergames sono stati salutati da subito come una novità positiva, per il contributo che offrono come arma contro uno stile di vita sedentario(Chamberlin and Gallagher 2008) e per il livello di coinvolgimento dell'utente, che unisce al tradizionale valore aggiunto dei videogames (Baranowski et al. 2008, Wigdor and Wixon 2011) l'attrattiva delle interfacce naturali (Wigdor and Wixon 2011).

L'attenzione si è dapprima concentrata sulla promozione di stili di vita salutari e sulla lotta alla sedentarietà, e pertanto l'attenzione si è concentrata sul consumo calorico e sull'aspetto energetico. (SIEGEL et al. 2009)

L'aspetto che più di frequente viene sottolineato negli studi che si sono occupati dell'argomento legato al consumo energetico è l'attrattiva esercitata dagli exergames su individui normalmente riluttanti all'attività fisica. Gli exergames, in altri termini, sono soprattutto un metodo per promuovere il benessere e incoraggiare al movimento soggetti che praticano stili di vita sedentari.

"Exergaming is a term used to describe video games that provide encouragement to exercise, particularly for an audience that may be reluctant to 
engage in the more traditional forms of exercise. Exergames are a commonly accepted method of encouraging more physical activity to promote better health for those with high levels of sedentary screen time" (Whitehead et al. 2010)

I risultati sono incoraggianti, considerato che il consumo calorico raddoppia nei soggetti coinvolti in videogames che coinvolgono l'intero corpo rispetto a individui che utilizzano giochi "tradizionali". (Lanningham-Foster et al. 2006)

Sulla scorta dei risultati positivi ottenuti, la ricerca ha esplorato altri campi, mostrando come l'attività videoludica basata sull'intero corpo possa portare benefici sul piano cognitivo nell'autismo o potenziare l'attività cerebrale nell'età avanzata.

"Exergaming may be useful for the management of behavioral disturbance and for increasing cognitive control in children on the autism spectrum" (Anderson-Hanley, Tureck and Schneiderman 2011) ; "Exergames' boost brain function among seniors" (Anderson-Hanley et al. 2012)

I risultati degli studi citati hanno avuto l'effetto di sovvertire il tradizionale scetticismo con cui spesso è stata considerata l'attività videoludica nell'ambito delle scienze motorie e dell'educazione alla salute.

\section{Metodo}

Il presente lavoro presenta un excursus della letteratura esistente sugli exergames e riassume lo stato dell'arte nella ricerca in questo campo, nel tentativo di individuare i fondamenti teorici e didattici dell'exergame design, per verificare se esistono exergames che siano riconducibili ad un preciso framework teorico nell'ambito della Physical Education o che siano espressamente orientati alla didattica o alla riabilitazione.

\section{Risultati}

La tendenza attuale è di considerare come i videogames presentino numerosi vantaggi potenziali in ambito motorio e di promozione del benessere. I principali punti di forza comuni, che possono influenzare positivamente abilità, atteggiamenti e comportamenti in materia di salute ed esercizio fisico, sono il fascino che questi giochi possiedono (e pertanto l'incremento della motivazione), nonché le opportunità che essi offrono per l'apprendimento attivo, esplorativo ed esperienziale di concetti e competenze, per il feedback personalizzato e l'istruzione personalizzata, e per l'apprendimento attraverso le interazioni sociali.

"Exergame present many potential benefits for HE and PE. [...] Pulling together those benefits, it derives that major common strengths for both disciplines, which may positively influence young people' knowledge, skills, 
attitudes and behaviours in relation to health and physical exercise, are the unique motivational appeal that those games possess as well as the opportunities that they offer for active, exploratory and experiential learning of concepts and skills, for rehearsal of skills within a safe environment, for individualized feedback and differentiated instruction, and for learning through social interactions. In addition, the new generation of physically interactive electronic games seems to be particularly valued in the overviewed literature as it can provide opportunities for actual physical exercise and motor skill learning within PE contexts." (Papastergiou 2009).

Tuttavia, altri studi hanno condotto a risultati meno entusiasmanti e rivelato i limiti degli exergames

Uno studio condotto da (Hsu et al. 2011) sugli effetti dell'utilizzo del Bowling per la console Wii in un regime di esercizio per degenti a lungo termine con disfunzione degli arti superiori ha dimostrato che l'unico dato significativo è stato un maggiore godimento dell'attività rispetto ad un gruppo di controllo sottoposto ad un regime standard

A study on "effects of adding Nintendo Wii ${ }^{\circledR}$ Bowling to a standard exercise regimen for residents of long-term care with upper extremity dysfunction" showed as "the only significant finding was a measure of enjoyment of activity when compared to a standard exercise group." (Tanaka et al. 2012)

Questo spinge a considerare come l'attuale generazione di exergames non sia progettata specificamente per essere di supporto alla didattica delle attività motorie o alla riabilitazione. Esistono prodotti general purpose, destinati a larghe fasce di utenza, ma software, prodotti sulla base di un robusto framework teorico, orientati alla acquisizione di specifiche motor skills, da utilizzare nell'ambito della didattica delle scienze motorie e della riabilitazione, sono ancora appannaggio della ricerca sperimentale e non conoscono una diffusione tale da poter tentare una stima globale delle ricadute cognitive e didattiche degli exergames.

La ricerca sull'effettiva efficacia degli exergames nella acquisizione di specifiche abilità motorie sembra ancora carente.

La conoscenza dei meccanismi fondamentali del controllo motorio e delle dinamiche legate all'apprendimento delle abilità motorie può costituire il supporto teorico al design e allo sviluppo di exergames. 


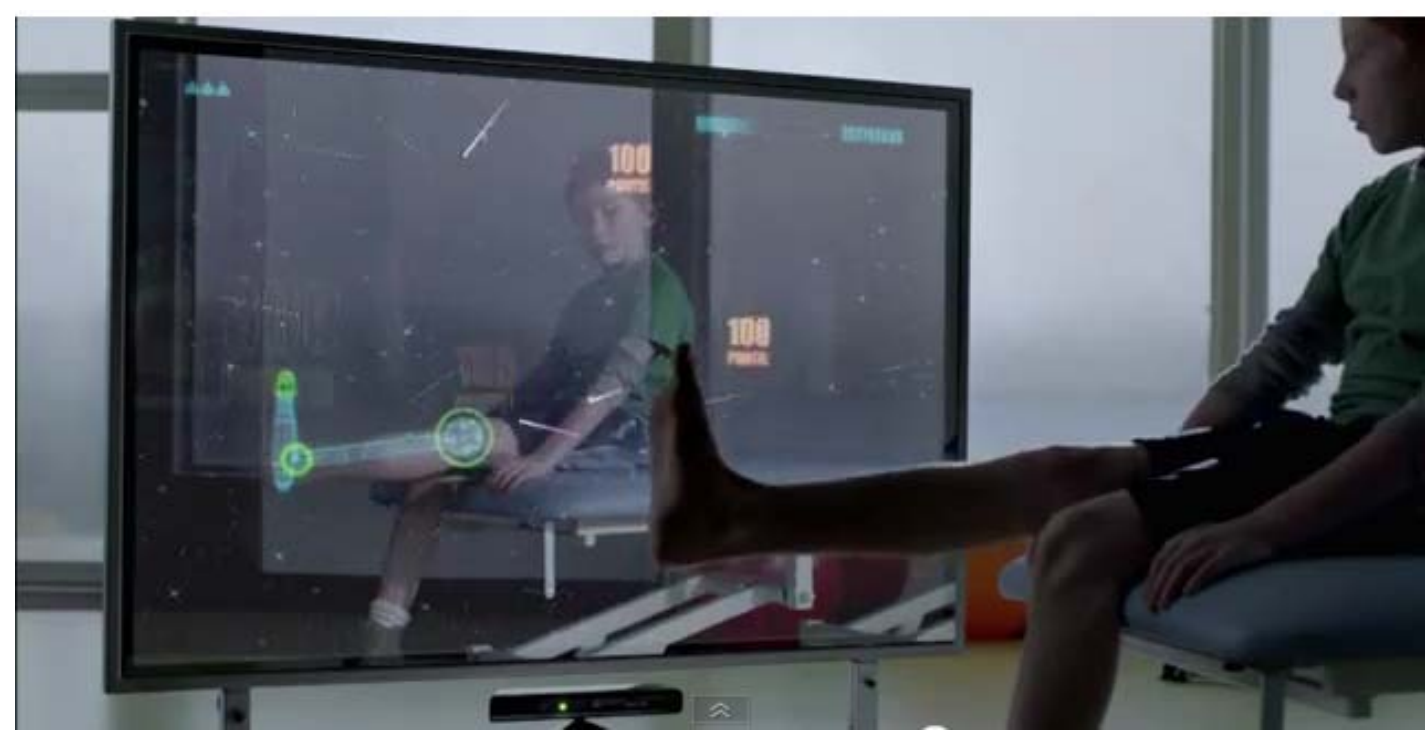

Figure 1 - Microft Kinect and motor control - da http://www.microsoft.com/enus/kinectforwindows

In questa sede, si fa riferimento alla definizione di controllo motorio proposta da Schmidt\&Wrisberg: "L'apprendimento motorio è un processo interno che riflette il livello di capacità individuale di prestazione e potrebbe essere valutato in base alla relativa stabilità delle esecuzioni di un compito." (Schmidt and Wrisberg 2008)

Le teorie sul controllo motorio sviluppate nell'ambito della psicologia cognitiva hanno generato una consistente mole di applicativi didattici. In base a queste teorie, l'essere umano possiede, a livello cerebrale, una serie di programmi motori, ovvero sequenze di comandi che, a livello del sistema nervoso centrale, coordinano l'esecuzione dei movimenti.

Apprendere movimenti consiste nello sviluppare strutture cognitive, denominate programmi motori, mediante processi di elaborazione delle informazioni. Questi processi consentono la possibilità di confrontare in tempo reale, controllo motorio a circuito chiuso (Adams 1971), o successivamente, controllo motorio a circuito aperto (Schmidt 1975, Schmidt and Wrisberg 2008), risultati ottenuti e risultati attesi, innescando un processo di correzione dell'esecuzione motoria.

Il programma motorio generalizzato "è un programma motorio che definisce un modello (pattern) di movimento; questa sua flessibilità consente di adattarlo in modo da produrre varianti del pattern motorio adattate a modificate richieste dell'ambiente"(Schmidt and Wrisberg 2008). La sua struttura è tale che consente all'esecutore di aggiustare il movimento al fine di far fronte a mutate esigenze dell'ambiente.

In alternativa a tali teorie, di approccio cognitivo, sono da annoverare altre di orientamento ecologico che in forma dinamica realizzano apprendimenti nell'interazione con l'ambiente. Esse sono l'imagery motoria, che trova 
un'evidenza scientifica nei neuroni specchio (Rizzolatti and Sinigaglia 2006, Iacoboni 2005)o, più indietro nel tempo, la teoria dei gradi di libertà (Bernshteřn 1967, Latash and Turvey 1996). Entrambe connotano gli apprendimenti motori come originati dall'esecutore immerso nell'ambiente di apprendimento senza l'intervento dell'insegnante/allenatore risultano particolarmente funzionali alla HCI (Human Computer Interaction).

"Because many exergames such as DDR or Wii Sports tennis require rapid hand-eye or foot-eye coordination, they may improve general coordination skills. However, the majority of research on coordination benefits involves elderly people playing sedentary video games, not exergames. Video game play increased perceptual-motor skills including hand-eye coordination, dexterity, and fine motor ability (Drew and Waters 1986). At present, there is no exergame research on this topic." (Staiano and Calvert 2011)

La prossima sfida per i ricercatori lo sviluppo di exergames fondati su una forte base scientifica ed orientati all'apprendimento di abilità motorie ed al controllo motorio, al fine di suggerire pratiche di effettivo utilizzo per trainer e docenti nell'ambito dell'attività didattica. 


\section{References}

- Adams, J. A. (1971) A closed-loop theory of motor learning. Journal of Motor Behavior; Journal of Motor Behavior.

- Anderson-Hanley, C., P. J. Arciero, A. M. B. DPE, J. P. Nimon, N. Okuma, S. C. Westen, M. E. Merz, B. D. Pence, J. A. Woods \& A. F. Kramer (2012) Exergaming and Older Adult Cognition.

- Anderson-Hanley, C., K. Tureck \& R. L. Schneiderman (2011) Autism and exergaming: effects on repetitive behaviors and cognition. Psychology research and behavior management, 4, 129.

- Baranowski, T., R. Buday, D. I. Thompson \& J. Baranowski (2008) Playing for real: Video games and stories for health-related behavior change. American journal of preventive medicine, 34, 74-82. e10.

- Bernshteĭn, N. A. 1967. The co-ordination and regulation of movements. Pergamon Press.

- Chamberlin, B. \& R. Gallagher. 2008. Exergames: Using video games to promote physical activity.

- Drew, B. \& J. Waters (1986) Video games: Utilization of a novel strategy to improve perceptual motor skills and cognitive functioning in the noninstitutionalized elderly. Cognitive Rehabilitation.

- Hsu, J. K., R. Thibodeau, S. J. Wong, D. Zukiwsky, S. Cecile \& D. M. Walton (2011) A "Wii" bit of fun: The effects of adding Nintendo Wiiß Bowling to a standard exercise regimen for residents of long-term care with upper extremity dysfunction. Physiotherapy Theory and Practice, 27, 185193.

- Iacoboni, M. (2005) Neural mechanisms of imitation. Current opinion in neurobiology, 15, 632-637.

- Lanningham-Foster, L., T. B. Jensen, R. C. Foster, A. B. Redmond, B. A. Walker, D. Heinz \& J. A. Levine (2006) Energy expenditure of sedentary screen time compared with active screen time for children. Pediatrics, 118, e1831-e1835.

- Latash, M. L. \& M. T. Turvey. 1996. Dexterity and Its Development. L. Erlbaum Associates.

- Papastergiou, M. (2009) Exploring the potential of computer and video games for health and physical education: A literature review. Computers \& Education, 53, 603-622.

- Rizzolatti, G. \& C. Sinigaglia. 2006. So quel che fai: il cervello che agisce ei neuroni specchio. R. Cortina ed. 
- Schmidt, R. A. (1975) A schema theory of discrete motor skill learning. Psychological review, 82, 225.

- Schmidt, R. A. \& C. A. Wrisberg. 2008. Motor learning and performance: a situation-based learning approach. Human Kinetics Publishers.

- SIEGEL, S. R., B. L. HADDOCK, A. M. DUBOIS \& L. D. WILKIN (2009) Active video/arcade games (exergaming) and energy expenditure in college students. International journal of exercise science, 2, 165.

- Staiano, A. E. \& S. L. Calvert (2011) Exergames for physical education courses: Physical, social, and cognitive benefits. Child Development Perspectives, 5, 93-98.

- Tanaka, K., J. Parker, G. Baradoy, D. Sheehan, J. R. Holash \& L. Katz (2012) A Comparison of Exergaming Interfaces for Use in Rehabilitation Programs and Research. Loading... 6.

- Whitehead, A., H. Johnston, N. Nixon \& J. Welch. 2010. Exergame effectiveness: what the numbers can tell us. 55-62. ACM.

- Wigdor, D. \& D. Wixon. 2011. Brave NUI world: designing natural user interfaces for touch and gesture. Morgan Kaufmann. 